\title{
Effect of Quinolones on Serum Testosterone Level in Male Albino Rats
}

\author{
Rubina Iqbal, ${ }^{1}$ Saud Iqbal, ${ }^{2}$ Shahzad Anjum ${ }^{3}$
}

\section{Abstract}

Objective: To determine the toxic effects of quinolones on serum testosterone level in male albino rats.

Methods: Eighty male albino rats were randomly divided into A, B, C and D groups each group having 20 albino rats. These groups were further subdivided into $\mathrm{A} 1, \mathrm{~A} 2, \mathrm{~B} 1, \mathrm{~B} 2, \mathrm{C} 1, \mathrm{C} 2, \mathrm{D} 1$ and D2 having 10 albino rats each. Ciprofloxcin, ofloxacin and enoxacin dissolved in distilled water were given at $135 \mathrm{mg} / \mathrm{kg} /$ day, $72 \mathrm{mg} / \mathrm{kg} /$ day and $12.5 \mathrm{mg} / \mathrm{kg} /$ day to groups A, B and $\mathrm{C}$ respectively for 12 weeks. Only distilled water was given to group D which was control group for the same time period. Blood samples were drawn for testosterone hormone level estimation at $0,14^{\text {th }}, 28^{\text {th }}$ and $42^{\text {nd }}$ day in subgroups $\mathrm{Al}, \mathrm{B} 1, \mathrm{Cl}$ and $\mathrm{D} 1$ and then the animals in said groups were sacrificed on $42^{\text {nd }}$ day to identify testicular morphological changes. Rats in subgroup A2, B2, C2 and D2 were kept alive till $84^{\text {th }}$ day after stopping drugs at 42 days to find out if there

\footnotetext{
${ }^{1}$ Assistant Professor of Pharmacology, King Edward Medical University, Lahore

${ }^{2}$ PG Trainee, Maxillofacial Surgery, Mayo Hospital, Lahore

${ }^{3}$ PG Trainee (Mphi) Pharmacology, King Edward Medical University, Lahore
}

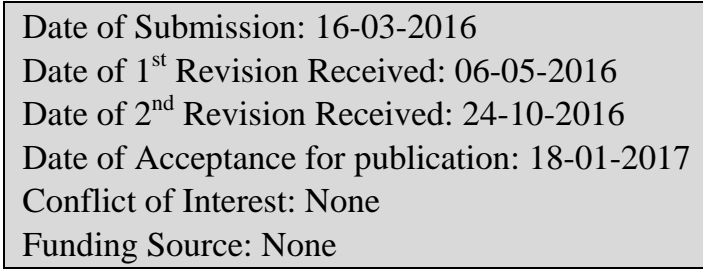

\section{Contribution}

All Authors have contributed in Study Design, Data Collection, Data Analysis, Data Interpretation, Manuscript Writing and Approval. is any change in levels of testosterone after discontinuation of the treatment. Blood samples for testosterone hormone estimation were taken at $0,14^{\text {th }}, 28^{\text {th }}$, $42^{\text {nd, }} 56^{\text {th }}, 70^{\text {th }}$ and $84^{\text {th }}$ day from subgroups A2, B2, C2 and D2. Testosterone hormone estimation assay was performed on the collected samples.

Results: Testosterone assay showed significant decrease in serum testosterone levels in all experimental groups, when compared with control group. These levels did not return back to normal even after withdrawal of drugs. This study suggests a gonadotoxic potential of quinolones.

Conclusion: Quinolones reduce serum testosterone levels and should be used carefully for long term therapy.

\section{Introduction}

Testosterone hormone is present in circulation, which is primarily the male sex hormone. Pituitary gland produces luteinizing hormone which causes secretion of testosterone from testes. Gonadotropin releasing hormone from hypothalamus regulates the secretion of luteinizing hormone. ${ }^{1}$ Testosterone circulates in blood by binding to albumin with low affinity or by binding to sex hormone-binding globulin (SHBG) with high affinity and a small fraction remains free or unbound. Only that testosterone is said to be bio available which is not bound to SHBG that includes both free testosterone and that is bound to albumin. Androgen receptors are activated by androgens that cause differentiation in prenatal sex characters, pubertal changes, growth and development of secondary male characteristics and consequently body conformation into adult male. Testosterone itself binds to androgen receptors but by its conversion into dihydrotestosterone the binding affinity to androgen receptors increases. Testo- 
sterone is converted into dihydrotestosterone by enzyme $5 \alpha$-reductase or it can be converted into estradiol by aromatase enzyme, estradiol binds with estrogen receptor. ${ }^{1,2}$ Low levels of serum testosterone are linked with certain mechanisms of metabolic syndrome including abdominal obesity, hypertension, insulin resistance, higher levels of inflammatory markers and increased risk of cardiovascular disease in non uremic patients. $^{3}$

There are variety of prescription medications that can leads to male infertility, often temporary but sometimes permanently. These medications include, antidepressants, anti-hypertensives, $\mathrm{H}_{2}$ receptor antagonists, disease modifying anti rheumatoid drugs, anticancer drugs and antibiotics. The antibiotics are often prescribed to deal with a variety of bacterial infections, often they are only taken for short period of time. Adverse effects on fertility are reversed after discontinuing the medication. Some of the antibiotics may be prescribed for longer time period which are suspected to interfere with the male fertility. These include nitrofurantoin, aminoglycosides, minocycline, macrolidies, sulfasalazine, and quinolones. ${ }^{4}$

The fluoroquinolones are synthetic broad spectrum anti-microbial agents which are effective orally for a wide variety of infectious diseases. They are very potent agents having bactericidal activity against E.Coli, and different species of Neisseria, Enterobacter, Shigella, Campylobacter and Salmonella. Several new quinolones have activity against anaerobic bacteria. ${ }^{5}$ The fluoroquinolones are very frequently prescribed for many clinical conditions. They have broad spectrum of antimicrobial activity and are considerably more potent for the infections of urinary tract. ${ }^{6}$ They are effectively used for prostatitis caused by sensitive bacteria and in sexually transmitted diseases like gonnorrhoea. Ciprofloxacin, ofloxacin and enoxacin cure most of the patients with typhoid or enteric fever that is caused by Salmonellatyphi. They are also used in respiratory tract, bone, joint and soft tissue infections. These may be used as part of multiple drug regimens for the treatment of multiple drug resistant tuberculosis and atypical mycobacterialinfections. $^{7}$

The rate of multiplication of germ cells is very high that makes the reproductive system very sensitive to the toxic chemicals. Chemotherapy causes toxic effects on male gonad. ${ }^{8,9}$ The toxic effects on reproductive system causes genetic damages which can be transferred from one generation to another. Keeping in view the mentioned facts it is very important to con- sider thesegenotoxic and cytotoxic effects of different agents. ${ }^{10}$ It is noticed from previous years that there is marked decline in male fertility. Misuse of important drugs like antibiotics is one of the factors that caused this decrease in male fertility, such as ciprofloxacin, ofloxacin and enoxacin which come under the heading of fluoroquinolones. ${ }^{11}$ Thus; in this study effects of ciprofloxacin, ofloxacin and enoxacin on serum testosterone levels were evaluated.

\section{Material and Method}

An experimental study was carried out at pharmacology department of Post Graduate Medical Institute, Lahore for the total duration of 84 days. Eighty (80) male Albino rats, 7 weeks of age having weight of 200 - 300 grams each were obtained from University of Veterinary and Animal Sciences Lahore. Ethical approval for animal study was taken from Ethical Committee of Post Graduate Medical Institute, Lahore. Animals were randomly divided into A, B, C and D groups having twenty (20) albino rats each. These groups were further subdivided into A1, A2, B1, B2, C1, C2, D1 and D2 having 10 albino rats each. Ciprofloxcin, ofloxacin and enoxacin dissolved in distilled water were given at $135 \mathrm{mg} / \mathrm{kg} /$ day, $72 \mathrm{mg} / \mathrm{kg} /$ day and $12.5 \mathrm{mg} / \mathrm{kg} /$ day to groups $\mathrm{A}, \mathrm{B} \& \mathrm{C}$ respectively for 12 weeks. Group D served as control and was given $0.5 \mathrm{ml}$ distilled water orally for the same time period. Ciprofloxacin tablet of $500 \mathrm{mg}$ was dissolved in $5 \mathrm{ml}$ of distilled water one $\mathrm{ml}$ contained $100 \mathrm{mg}$ of ciprofloxacin. Insulin syringe was used which has 100 sub divisions per $\mathrm{ml}$ and each sub division of $0.01 \mathrm{ml}$ contained $1 \mathrm{mg}$ of ciprofloxacin. Then dosage for each albino rat was calculated according to the weight and orally administered.

Ofloxacin tablet of $400 \mathrm{mg}$ was dissolved in $4 \mathrm{ml}$ of distilled water so one $\mathrm{ml}$ contained $100 \mathrm{mg}$ of ofloxacin. Then dosage for each albino rat was calculated according to the weight and given orally.

Enoxacin tablet of $400 \mathrm{mg}$ dissolved in $4 \mathrm{ml}$ of distilled water so one $\mathrm{ml}$ contained $100 \mathrm{mg}$ of enoxacin. Then dosage for each albino rat was calculated according to the weight and given orally:

Standard doses were used as calculated by the above mentioned formulas. Standard doses are converted into $\mathrm{mg} / \mathrm{kg}$ to adjust the dose according to the weights of the animals. Blood samples were drawn by cardiac puncture under light anesthesia at $0,14^{\text {th }}, 28^{\text {th }}$ and $42^{\text {nd }}$ day from subgroups $\mathrm{Al}, \mathrm{B} 1, \mathrm{Cl}$ and $\mathrm{D} 1$, then the animals in said groups were sacrificed to find out 
the morphological changes at $42^{\text {nd }}$ day. Drugs and distilled water were discontinued till the end of the study i.e. $84^{\text {th }}$ day in subgroups A2, B2, C2 and D2 to find out if there is any change in levels of testosterone after discontinuation of the treatment. Blood samples for testosterone hormone estimation were taken at 0 , $14^{\text {th }}, 28^{\text {th }}, 42^{\text {nd }}, 56^{\text {th }}, 70^{\text {th }}$ and $84^{\text {th }}$ day from subgroups A2, B2, C2 and D2 using same technique. Testosterone hormone estimation assay was performed on the collected samples using enzyme immunoassay (EIA) technique. Blood was centrifuged for $30 \mathrm{mins}$, serum was separated. The serum was assayed for testosterone hormone. Serum testosterone levels were determined by CENUM (Center for Nuclear Medicine) Mayo Hospital, Lahore. Statistical analysis was done by using SPSS version 16.ANOVA was used to compare the serum testosterone in different groups and $\mathrm{P}$ value $<0.05$ was taken as significant.

\section{Results}

Normal range of serum testosterone levels in rat ranges from 0.66 to $5.4 \mathrm{ng} / \mathrm{ml}^{12}$ Serum testosterone level at day zero in the study group was $1.01 \pm 0.36$ $\mathrm{ng} / \mathrm{ml}$ in group $\mathrm{A} 1,0.9 \pm 1.02 \mathrm{ng} / \mathrm{ml}$ in $\mathrm{A} 2,1.01 \pm$ $0.36 \mathrm{ng} / \mathrm{ml}$ in B1, $1.32 \pm 0.99 \mathrm{ng} / \mathrm{ml}$ in $\mathrm{B} 2,1.12 \pm 0.34$ $\mathrm{ng} / \mathrm{ml}$ in $\mathrm{C} 1,1.48 \pm 1.21 \mathrm{ng} / \mathrm{ml}$ in $\mathrm{C} 2,1.55 \pm 0.63$ $\mathrm{ng} / \mathrm{ml}$ in D1 and $1.20 \pm 0.68 \mathrm{ng} / \mathrm{ml}$ in D2. The mean serum testosterone was statistically same in control groups as compared to experimental groups with $\mathrm{p}$ value $<0.05$. There was insignificant mean difference in average serum testosterone level in all pair wise comparison.

The serum testosterone level at $\mathbf{1 4}^{\text {th }}$ day was $0.71 \pm$ $0.24 \mathrm{ng} / \mathrm{ml}$ in A1, $0.64 \pm 0.41 \mathrm{ng} / \mathrm{ml}$ in A2, $0.70 \pm 0.26$ $\mathrm{ng} / \mathrm{ml}$ in $\mathrm{B} 1,0.88 \pm 0.52 \mathrm{ng} / \mathrm{ml}$ in $\mathrm{B} 2,0.90 \pm 0.34$ $\mathrm{ng} / \mathrm{ml}$ in $\mathrm{C} 1,1.26 \pm 1.08 \mathrm{ng} / \mathrm{ml}$ in $\mathrm{C} 2,1.86 \pm 0.65$ $\mathrm{ng} / \mathrm{ml}$ in D1 and $1.62 \pm 0.57 \mathrm{ng} / \mathrm{ml}$ in D2. The mean serum testosterone level at $14^{\text {th }}$ day was statistically higher in control group as compared to experimental groups (p-value < 0.05) except C2 (p-value > 0.05). The pairs A1 vs. C2, A1 vs. D1, A1 vs. D2, A2 vs. C2, $\mathrm{A} 2$ vs. D1, A2 vs. D2, B1 vs. C2, B1 vs. C2, B1 vs. D2, B2 vs. D1, B2 vs. D2, C1 vs. D1, C1 vs. D2, and C2 vs. D1 were statistically significant while all other pairs were insignificant in this study.

The serum testosterone level at $\mathbf{2 8}^{\text {th }}$ day, in group A1 was $3.00 \pm 0.00 \mathrm{ng} / \mathrm{ml}$, in A2 was $0.44 \pm 0.29$ $\mathrm{ng} / \mathrm{ml}$, in B1 was $0.53 \pm 0.20 \mathrm{ng} / \mathrm{ml}$, in $\mathrm{B} 2$ was $0.69 \pm$ $0.41 \mathrm{ng} / \mathrm{ml}$, in C1 was $2.01 \pm 0.63 \mathrm{ng} / \mathrm{ml}$, in $\mathrm{C} 2$ was $2.27 \mathrm{ng} / \mathrm{mlin} \mathrm{D} 1$ was $2.02 \pm 0.63 \mathrm{ng} / \mathrm{ml}$ and D2 was
$1.76 \pm 0.57 \mathrm{ng} / \mathrm{ml}$. The mean serum testosterone level was statistically lower in control group as compared to A1 and higher as compared to group B1 (p-value < 0.05 ) while it was statistically same in $\mathrm{C} 1$ (p-value > $0.05)$. The mean serum testosterone level was also statistically higher in control group as compared to A2 and B2 (p-value < 0.05) while it was same in C2 (pvalue $>0.05)$ at $28^{\text {th }}$ day. The pairs $A 2$ vs. B1, A2 vs. B2, B1 vs. B2, C1 vs. C2, C1 vs. D1, C1 vs. D2, C2 vs. D1, C2 vs. D2, and D1 vs. D2 were statistically insignificant while all other pairs were significant.

The serum testosterone level at $\mathbf{4 2}^{\text {nd }}$ day in group A1 was $0.38 \pm 0.15 \mathrm{ng} / \mathrm{ml}$, in $\mathrm{A} 2$ was $0.21 \pm 0.14$ $\mathrm{ng} / \mathrm{ml}$, in B1 was $0.31 \pm 0.13 \mathrm{ng} / \mathrm{ml}$, in B2 was $0.46 \pm$ $0.28 \mathrm{ng} / \mathrm{ml}$, in $\mathrm{C} 1$ was $1.96 \pm 0.60 \mathrm{ng} / \mathrm{ml}$, in $\mathrm{C} 2$ was $0.83 \pm 0.78 \mathrm{ng} / \mathrm{ml}$, in D1 was $1.96 \pm 0.60 \mathrm{ng} / \mathrm{ml}$ and in group D2 $1.81 \pm 0.49 \mathrm{ng} / \mathrm{ml}$. The mean serum testosterone level was statistically higher in control group as compared to $\mathrm{A} 1$ and $\mathrm{B} 1$ ( $\mathrm{p}$-value $<0.05)$, while it was statistically same in $\mathrm{C} 1$ (p-value > 0.05). The mean serum testosterone at $42^{\text {nd }}$ day was also statistically higher in controlled group as compared to all experimental groups (A2, B2 and C2) (p-value $</ \mathrm{ml}$ $0.05)$. The pairs $\mathrm{A} 1$ vs. $\mathrm{A} 2, \mathrm{~A} 1$ vs. $\mathrm{B} 1, \mathrm{~A} 1$ vs. $\mathrm{B} 2, \mathrm{~A} 2$ vs. B1, A2. B2, B1 vs. B2, C1 vs. D1, C1 vs. D2, and D1 vs. D2 were statistically insignificant while all the rest of pairs were significant.

After $\mathbf{4 2}^{\text {nd }}$ day subgroups A1, B1, C1 and D1 were sacrificed to find out the testicular morphological changes and drug treatment was discontinued in subgroups A2, B2 and C2 and distilled water was discontinued to subgroup D2 which was acting as control. Afterwards, serum testosterone levels were only estimated for subgroups A2, B2, C2 and D2. The serum testosterone level at $56^{\text {th }}$ day was $0.24 \pm 0.15 \mathrm{ng} / \mathrm{ml}$ in group A2, $0.50 \pm 0.32 \mathrm{ng} / \mathrm{ml}$ in B2, $0.97 \pm 0.78 \mathrm{ng} / \mathrm{ml}$ in $\mathrm{C} 2$ and $1.90 \pm 0.56 \mathrm{ng} / \mathrm{ml}$ in D2. The mean serum testosterone level at $56^{\text {th }}$ day was statistically higher in control group as compared to all experimental groups (p-value $<0.05$ ) sacrificed at $84^{\text {th }}$ day.

The serum testosterone level at $\mathbf{7 0}^{\text {th }}$ day was 0.47 $\pm 0.30 \mathrm{ng} / \mathrm{ml}$ in group $\mathrm{A} 2,0.45 \pm 0.30 \mathrm{ng} / \mathrm{ml}$ in $\mathrm{B} 2$, $1.01 \pm 0.81 \mathrm{ng} / \mathrm{ml}$ in $\mathrm{C} 2$ and $1.99 \pm 0.59 \mathrm{ng} / \mathrm{ml}$ in D2 The mean serum testosterone level at $70^{\text {th }}$ day was statistically higher in control group as compared to all experimental groups ( $\mathrm{p}$-value $<0.05$ ) sacrificed at $84^{\text {th }}$ day.

The serum testosterone level at $84^{\text {th }}$ day was 0.52 $\pm 0.48 \mathrm{ng} / \mathrm{ml}$ in group A2, $0.74 \pm 0.48 \mathrm{ng} / \mathrm{ml}$ in B2, $0.99 \pm 0.79 \mathrm{ng} / \mathrm{ml}$ in $\mathrm{C} 2$ and $2.04 \pm 0.55 \mathrm{ng} / \mathrm{ml}$ in D2 The mean serum testosterone level at $84^{\text {th }}$ day was 
statistically higher in control group as compared to all experimental groups $(\mathrm{p}$-value $<0.05)$ sacrificed at $84^{\text {th }}$ day.

\section{Discussion}

The fluoroquinolones are synthetic broad spectrum anti-microbial agents which are effective for a wide variety of infectious diseases. The therapeutic and adverse effects of fluoroquinolones have been well documented. However, the result of our experimental study revealed that prolonged administration of therapeutic doses of fluoroquinolones such as ciprofloxacin, ofloxacin and enoxacin promoted reproductive toxicity in rats. The reduction in serum testosterone levels are the evidence for this toxicity.

It was seen by Nancy et al. (1989) that fluoroquinolone such as ciprofloxacin, which causes inhibition of oxidative drug metabolism has no anti-steroidogenic side effects. ${ }^{13}$ No significant effect was found on concentration of testosterone with ciprofloxacin, when the baseline concentrations of testosterone were compared with the concentrations obtained after single and multiple doses administrations of ciprofloxacin. The absence of the effect in case of ciprofloxacin at therapeutic doses could be due to its relative selectivity for P450 isozyme or low inhibitory potency, but at the end of the study testosterone assay showed significant decrease in the serum testosterone hormone levels in all experimental groups having $\mathrm{P}<0.05$ which is significant. Difference between experimental groups is not significant, i.e. all the three fluoroquinolones are equal inhibitors of testosterone synthesis.

It is evident that even after discontinuation of the drugs after $42^{\text {nd }}$ day of treatment serum testosterone did not return back to the normal levels. This seems to be due to necrosis of the interstitial leydig cells which probably would have resulted in decrease synthesis of testosterone hormone. ${ }^{14,15}$

This study was conducted on male albino rats only; to increase the spectrum of the conclusions it may also be repeated on different other animals.

\section{Conclusion}

The present study concludes that the use of quinolones results in reduction of testosterone levels; however, more research work is required to find out the toxicity and exact mechanism operating at cellular level which suppresses the synthesis of testosterone.
This study however adds concern to the widespread and indiscriminate use of fluoroquinolones and recommends that these drugs should be used with great caution.

\section{References}

1. Bhasin S. Testicular disorders. In: Kronenberg HM, Melmed S, Polonsky KS, Larsen PR (eds). Williams Textbook of Endocrinology, $11^{\text {th }}$ ed. Saunders, Elsevier: Philadelphia. 2008; 645-699.

2. Jones ME, Boon WC, McInnes K, Maffei L, Carani C, Simpson ER. Recognizing rare disorders: aromatase deficiency. Nature clinical practice Endocrinology \& metabolism. 2007; 3 (5): 414-21.

3. Yeap BB. Are declining testosterone levels a major risk factor for ill-health in aging men? International journal of impotence research. 2009; 21 (1): 24-36.

4. Demir A, Turker P, Onol FF, Sirvanci S, Findik A, Tarcan T. Effect of experimentally induced Escherichia coli epididymo-orchitis and ciprofloxacin treatment on rat spermatogenesis. International journal of urology: official journal of the Japanese Urological Association. 2007; 14 (3): 268-72.

5. Stahlmann R. Quinolones. Encyclopedia of Molecular Pharmacology. 2008: 1055-8.

6. Warren JW, Abrutyn E, Hebel JR, Johnson JR, Schaeffer AJ, Stamm WE. Guidelines for antimicrobial treatment of uncomplicated acute bacterial cystitis and acute pyelonephritis in women. Clinical Infectious Diseases. 1999; 29 (4): 745-59.

7. Venugopal D, Kumar S, Isa M, Bose M. Drug resistance profile of human Mycobacterium avium complex strains from India. Indian journal of medical microbiology. 2007; 25 (2): 115.

8. Horstman MG, Meadows GG, Yost GS. Separate mechanisms for procarbazine spermatotoxicity and anticancer activity. Cancer research. 1987; 47 (6): 1547-50.

9. Zhang QX, Yang GY, Li JT, Li WX, Zhang B, Zhu W. Melamine induces sperm DNA damage and abnormality, but not genetic toxicity. Regulatory toxicology and pharmacology: RTP. 2011; 60 (1): 144-50.

10. Bairy KL, Kumar G, Rao Y. Effect of acyclovir on the sperm parameters of albino mice. Indian journal of physiology and pharmacology. 2009; 53 (4): 327-33.

11. Abd-Allah AR, Gannam BB, Hamada FM. The impact of ofloxacin on rat testicular DNA: application of image analysis. Pharmacological research: the official journal of the Italian Pharmacological Society. 2000; 42 (2): $145-50$.

12. Diagnostics A. Mouse/Rat Testosterone ELISA. In: Diagnostics A, editor. 2013.

13. Waite NM, Edwards DJ, Arnott WS, Warbasse LH. Effects of ciprofloxacin on testosterone and cortisol concentrations in healthy males. Antimicrobial agents 
and chemotherapy. 1989; 33 (11): 1875-7.

14. Kianifard D, Sadrkhanlou RA, Hasanzadeh S. The Ultrastructural Changes of the Sertoli and Leydig Cells Following Streptozotocin Induced Diabetes. Iranian Journal of Basic Medical Sciences. 2012; 15 (1): 62335.
15. Hong CY, Park JH, Ahn RS, Im SY, Choi H-S, Soh J, et al. Molecular Mechanism of Suppression of Testicular Steroidogenesis by Proinflammatory Cytokine Tumor Necrosis Factor Alpha. Molecular and Cellular Biology. 2004; 24 (7): 2593-604. 